\title{
Cultura e Nazione. Riflessioni sull'idea moderna di appartenenza
}

Culture et nation. Réflexions sur l'idée moderne d'appartenance

\section{Heinz Wismann}

\section{(2) OpenEdition \\ Journals}

Edizione digitale

URL: http://journals.openedition.org/etudesbalkaniques/392

ISSN: 2102-5525

\section{Editore}

Association Pierre Belon

\section{Edizione cartacea}

Data di pubblicazione: 1 gennaio 1999

Paginazione: 13-18

ISBN: 2-910860-09-4

ISSN: $1260-2116$

\section{Notizia bibliografica digitale}

Heinz Wismann, «Cultura e Nazione. Riflessioni sull'idea moderna di appartenenza », Études balkaniques [En ligne], 6 | 1999, mis en ligne le 08 avril 2009, consulté le 23 avril 2019. URL : http:// journals.openedition.org/etudesbalkaniques/392

Questo documento è stato generato automaticamente il 23 aprile 2019

Tous droits réservés 


\section{Cultura e Nazione. Riflessioni sull'idea moderna di appartenenza}

Culture et nation. Réflexions sur l'idée moderne d'appartenance

Heinz Wismann

\section{AUTORE}

HEINZ WISMANN

E.H.E.S.S.-Paris, Centre d'études et de recherches allemandes 